\title{
An Analysis of the Impact of Shareholder Activism in Corporate Governance: The Case of the Zimbabwean Banking Sector
}

\author{
Zenzo Lusaba Dube \\ Nyasha Mutsura Mkumbiri \\ National University of Science and Technology- Institute of Development Studies, Bulawayo, Zimbabwe \\ Email address: zenzo123@aol.com
}

Doi:10.5901/mjss.2014.v5n25p11

Abstract

The shareholder-manager relationship is the most essential framework in corporate governance. A good corporate governance system is one which is able to tackle the conflicts of interest between managers and owners of a corporation and resolve them. The behavioural aspects such as 'short termism', 'absentee landlords' and the agency problem weaken corporate governance structures. Shareholder activism enables shareholders to assert their rights, in order to influence corporations' behaviour. The study sought to analyse the impact of shareholder activism in Zimbabwe's banking sector. In Zimbabwe, the concept of shareholder activism remains rather obscure; it has not gained much currency. The banking sector plays an important role as financial intermediary and is a primary source of financing for the domestic economy. The sector has seen the collapse of many banks, largely attributed to poor corporate governance practices. It is in this light that the study submits that shareholder activism is an integral aspect of corporate governance. The study drew on the views of stakeholders in the banking sector and was inherently qualitative. A total of 8 banks and 1 building society were studied. Questionnaires and focus group discussions were carried out. The interviews were with a major institutional shareholder. The study unearthed a positive relationship between shareholder activism and corporate governance. Indeed it can be posited that shareholder activism can reduce the agency problem and increases accountability. Shareholder activism in the banking sector needs to be vibrant.

Keywords: Shareholder activism, Corporate Governance, Banks, Shareholders

\section{Introduction}

Shareholder activism has been on the rise and it has been regarded as one of the principles that affect corporate governance. Governance issues have taken centre stage in the development discourse and in particular on Africa's development agenda. This is largely due to the fact that most of Africa's problems have in the last forty-five years been linked to governance issues (Dyck, 2001). In Zimbabwe shareholder activism is still a nascent phenomenon which needs much attention so as to evaluate its impact in solving a series of corporate governance scandals that have unsettled the banking sector. The study sought to analyse the impact of shareholder activism in Zimbabwe's banking sector. A number of banks in Zimbabwe have engaged in what can be described as questionable business practices. It is in this light that the study submits that shareholder activism should be an integral part of corporate governance. Accountability is an integral element of corporate governance. Accountability can be achieved through shareholder activism. In Zimbabwe, the concept of shareholder activism remains rather obscure; it has not gained momentum. This is in sharp contrast to the developed world and South Africa where shareholder activism is part and parcel of the corporate governance framework. Shareholder activism enables shareholders to assert their powers as owners, in order to influence corporations' behaviour; by exercising their rights. Shareholder activism is therefore a means of getting board and management to recognise the needs of the shareholders.

The Zimbabwean banking sector has been facing challenges in practicing proper corporate governance principles. The Zimbabwean banking sector plays an important role as financial intermediary and is a primary source of financing for the domestic economy. The sector has seen the collapse of many banks which has been attributed to poor corporate governance practices and the agency problem. The collapse of the banks has mainly been attributed to the agency problem. Activism can be in the form of making positive use of voting rights, engagement and dialogue with the directors of investee companies, paying attention to board composition or governance of investee companies. While shareholders do not run companies there are ways in which they can influence the board. These ways range from dialogue with management over their concerns about particular issues to formal proposals that are voted on at annual general 
meetings (Chikura, 2012). Activism includes "voting with one's feet" by walking out of a meeting that requires a contribution from shareholders as a way of showing disapproval of what is proposed on the table. In light of the preceding arguments the study was guided by the following set of research questions:

- Is shareholder activism an important principle of corporate governance in the banking sector?

- To what extent does shareholder activism affects corporate governance?

- Does shareholder activism solve the agency problem?

- Is there any relationship between shareholder activism and the performance of the banking sector?

\section{Literature Review}

Shareholder activism arose out of a desire to improve corporate governance. Since the late 1980's, shareholder activism has played a predominant role in efforts to reform corporate governance structures and improve firm performance (Becht, Franks, Mayer and Rossi, 2006). The review is in two parts. The first part reviews shareholder activism as a means of solving the agency problem. The second reviews shareholder activism in Zimbabwe

\subsection{Shareholder activism as a means to solve the agency problem.}

Discourses on corporate governance are often closely linked to the problem created by the separation of a firm's ownership from its control (Jensen and Meckling, 1976). Simply put corporate governance describes an apparent attempt by the corporate sector to ensure that its house is in order (Jackson and Carter, 1995). In other words corporate governance discussions embody the tussles between managers of public companies and their owners, over the productive level of shareholder involvement in corporate policy and administration (Schacht, 1995). The tussles are expressed through shareholder activism. When institutional investors are studied as potential mitigators of agency problems, it is implicitly assumed that institutional investors have the same objectives as other shareholders. Institutional investors, however, are often agents themselves managing funds that are not their own (Black, 1992a).

Shareholder activism is not a homogeneous practice, but comes in various guises; it is driven by different actors and interests, and has different impact on target firms. While the agency theory is important, it is highly controversial, in some ways limited (Fama and Jensen, 1983; Jensen and Meckling, 1976) and could be complemented by the institutional accounts of corporate governance (Aguilera and Jackson 2003; Aguilera 2005). These institutional accounts focus on the deeper and more resilient aspects of social structure, considering the processes by which structures (schemes, rules, norms, and routines) become established as authoritative guidelines for social behavior (Scott, 2004). It is thus important that corporate governance discussions reflect a broader perspective of institutional domains and the literature is responding to this insight (Aguilera and Jackson 2003, Aguilera 2005).

Whilst the literature remains dominated by notable works in developed countries, such as in the United States (Gillan and Starks, 2007), the United Kingdom (Becht et al. , 2006), the Netherlands, Japan (Seki, 2005) and Australia (Anderson et al. 2007), some seminal discourses of the subject have also been generated in emerging economies such as in India (Sarkar and Sarkar 2000). Despite increasing noteworthy works for example, the vacuum in literature on corporate governance and shareholder activism in sub Saharan Africa is very apparent. Maximization of shareholder wealth is usually affected by poor governance structures and decisions which are short term and for the benefit of the directors. This sacrifices future goals of the organization at the expense of short term benefits of the organization (Adegbite, et al. 2009).

Corporate governance has incorporated shareholder activism as an important principle. Several recent legal and regulatory changes have made it easier for shareholders to engage in activist behaviour. These changes are important from the perspective of shareholders, because an effective legal system that protects their ownership rights is a prerequisite for efficient corporate governance. While managers have a fiduciary duty to act in the interest of shareholders, they sometimes seek to maximize their own benefits instead. This creates a need for shareholders to monitor firms' management. In order to placate shareholders, internal and external corporate governance mechanisms are implemented to keep management's interests in line with those of the shareholders. Examples of internal mechanisms are effectively structured board, incentives schemes, and intense ownership holdings that encourage monitoring of executives. 


\subsection{Shareholder activism in Zimbabwe}

Takawira (2012) notes that shareholder activism is lacking in the Zimbabwean banking sector. Companies should encourage shareholder activism. Mucheche (2012) argued that shareholder activism can lead to corporate failure if one major shareholder dominates through their substantial shareholding. The impact of good corporate governance on bank survival cannot be over emphasized (Gono, 2012). In 2003 to 2004 a number of banks were forced to close down in what has now been termed the Zimbabwean Banking Crisis. The main cause of this banking crisis was mainly poor corporate governance practices by management. In Zimbabwe the number of financial institutions declined from forty as at 31 December 2003 to twenty nine (29) as at 31 December 2004 (Reserve Bank of Zimbabwe, 2005). Some financial institutions were forced to close down and others were placed under curatorship. Tsumba (2011) (The former Governor of RBZ) notes that shareholders in Zimbabwe are generally not sophisticated. They do not attend meetings, and those that attend fail to ask meaningful pertinent questions. The legal framework in Zimbabwe needs to be improved to ensure that banks play a more active corporate governance role (ibid). Mutambanadzo et al., (2013) posits that most issues addressed by shareholder activists in Zimbabwe relate to increases in shareholder value through changes in corporate policy, financing structure, or cost cutting measures. The various geographic locations do not allow most shareholders in Zimbabwe to participate in annual general meetings (ibid). As such their opinions and needs do not feature in the corporate outcomes. Mutambanadzo et al., (2013) stated that most of the shareholders do not even exercise their option of using a proxy vote and further advocates for employee ownership schemes. It is argued that employee ownership share schemes can curb the agency problem as the latter would have incentives not to defect. This can be likened to the Prisoners Dilemma. The rewards must outweigh the temptation so as to minimize agent defection.

\section{Research Methodology}

Nine banks were involved in this study. The sample banks comprised of four commercial banks, two merchant banks, two building societies and one savings bank. The banks sampled were from City of Bulawayo branch. Banks operating in Zimbabwe tend to locate their Head Offices in Harare, the capital city. Three were international banks and six local ones. Bulawayo is the second largest City in Zimbabwe. Selected finance directors, financial accountants, managing directors, shareholders and the general public were interviewed through the questionnaire method.Semi-structured interviews were carried out with a major key informant, a leading institutional investor. Focus group discussions (FDGs) were also carried out. The majority of the participants in this study requested anonymity..

\section{Findings and Discussion}

\subsection{Data presentation from Questionnaires}

The various sets of questions on the questionnaire targeted different groups. The groups constituted namely managers of banks (general managers), shareholders, accountants and the general public (customers). Some questions targeted different groups and some were common across the platform. Questions regarding the banks were directed at managers and were derived from the research questions.

\subsection{Questionnaire Responses}

Sixty five percent of the total respondents of 58 successfully completed the questionnaires. The general public had the highest response rate, followed by the shareholders with the least response rate emanating from general managers.

Table 1. The number of respondents as per each category

\begin{tabular}{|l|c|c|}
\hline Category & Number & Percentage of the Total Population \\
\hline General Managers & 9 & 15.5 \\
\hline Accountants & 10 & 17.2 \\
\hline Shareholders & 19 & 32.8 \\
\hline General Public (customers) & 20 & 34.5 \\
\hline Total & 58 & 100 \\
\hline
\end{tabular}

Source: Primary data 
Out of 58 respondents, 8 general public individuals were not aware of what shareholder activism and corporate governance was.

Table 2: The Distribution of Respondents by Status or Qualification

\begin{tabular}{|c|c|c|}
\hline Qualifications & Frequency & \% Respondents \\
\hline 'O' Level Only & 4 & 6.9 \\
\hline 'A' Level only & 8 & 13.8 \\
\hline Diploma & 29 & 50 \\
\hline Degreed??? & 15 & 25.9 \\
\hline Post graduate & 2 & 3.4 \\
\hline PhD & 0 & 0 \\
\hline Total & 58 & 100 \\
\hline
\end{tabular}

Source: Primary data

Table 2 above indicates the distribution of respondents by qualification. Respondents with Ordinary Level were the general public which represent only $(6.9 \%)$ of the total respondents while those with professional diplomas were the shareholders and accountants which represent the bulk of the total percentage of (50\%) and those with first degrees were managers contributing (25.9\%) whilst those with post graduate qualifications were only two managers. The results indicate that none of the respondents possessed post graduate degrees. The corresponding Figure 4.4 looks specifically on the employment status of the respondents. The bulk of the respondents attained tertiary education. Eighty one percent of the respondents were in substantive positions. These respondents held influential posts which had a direct bearing on their corporate entities' decision making process(these were 9 managers, 10 accountants, 11 shareholders, 17 general public) and $6.9 \%$ of them were in acting capacities.

Table 3. Response rate on questionnaires

\begin{tabular}{|l|c|c|c|}
\hline & $\begin{array}{c}\text { Number of questionnaires } \\
\text { Forwarded }\end{array}$ & $\begin{array}{c}\text { Number of questionnaires } \\
\text { Answered }\end{array}$ & $\begin{array}{c}\text { Response rate } \\
(\%)\end{array}$ \\
\hline General Managers & 15 & 9 & 60 \\
\hline Accountants & 20 & 10 & 50 \\
\hline Shareholders & 25 & 19 & 76 \\
\hline General Public & 30 & 20 & 66.7 \\
\hline Total & 90 & 58 & 63.2 \\
\hline
\end{tabular}

Source: Primary data

Shareholders had the highest response rate to questionnaires of (76\%). This implied that shareholders were more keen on shareholder activism than other groups in the study. Local banks indicated low levels of shareholder activism compared to international banks. The international banks exhibit high levels of shareholder activism due to the fact that their parent companies are stationed abroad. Most bank managers felt shareholder activism was a sensitive and contentious issue and therefore requested strict confidentiality.Commercial banks dominated other types of banks in the sample. This is largely due to the fact that they are in the majority in numbers in Zimbabwe. It was noted that the level of shareholder activism was high among the commercial banks followed by building society. The savings bank had the least as it is State owned. Commercial banks are largely complex by their very nature and attract high levels of shareholder activism. They have complex tier corporate governance structures. All the banks indicated that they have been in operation for more than 5 years. There was a positive correlation between shareholder activism and the number of years the bank has been in existence. Banks which have been in operation for many years exhibited high levels of shareholder activism compared to those with few years of operation. All the bank managers indicated that there had a stated policy on shareholder activism. That being said, the inverse holds true in reality, on the ground shareholder activism is passive. Shareholders pointed out that the costs associated with activism, the corporate politics or lack of knowledge (on the part of the shareholders) attributed the low level of shareholder activism in Zimbabwe. Out of 58 respondents 9 general managers, 10 Accountants, 19 shareholders and 12 general public (clients) understood the concepts of shareholder activism and corporate governance. 
Eight general managers, 4 accountants, 10 shareholders and 4 general public individuals indicated that shareholder activism positively affects corporate governance. 6 accountants, 4 shareholders and 8 general public individuals indicated that shareholder activism negatively affects corporate governance. A total of 5 shareholders, 8 general public individuals and 1 (one) manager indicated that they were indifferent as to how shareholder activism affects corporate governance. Most shareholders and general managers indicated that shareholder activism positively affects corporate governance. No general manager indicated that shareholder activism negatively affects corporate governance. This confirms that the managers were aware that shareholder activism could increase the level of corporate governance in the banking sector. Managers are in positions of authority which can influence decision making. They could therefore emancipate and environment conducive for shareholder activism. It can be noted that shareholders and managers were well aware of the importance of activism and the agency problem. Shareholder activism can reduce the agency problem. All the nine managers and $88 \%$ of the shareholders were of the view that shareholder activism, if properly implemented can and could attract investment. Activism is mainly through participation at annual general meetings (80\% of the responses), followed by participation through contacts with other shareholder recording (9\%). The reason is that annual general meetings (AGMs). Company Law makes AGMs mandatory. Participation at the AGM is the highest form of activism in Zimbabwe. The managers acknowledged that bank policies affected the implementation of shareholder activism. All the managers concurred that shareholder activism can reduce corporate governance scandals. However $34 \%$ of the shareholders argued that activism cannot not reduce corporate governance scandals if the shareholders did not have at hand, up to date state of affairs bank information. The majority of the accountants and the general public indicated that shareholder activism can reduce corporate governance scandals.

Seventy three percent of the managers pointed out the consequences associated with lack of shareholder activism. Bank fraud, poor management, the agency problem and lack of independence were some of the cited consequences. However $27 \%$ of the managers suggested that activism can at times bring in confusion. They stated that a bank can operate well without any activism as long there is independence in place. Shareholder activism can be a hindrance if the shareholders are not well informed and sophisticated as far as their roles in the corporate governance sphere is concerned. The managers and shareholders held that shareholder activism can reduce the agency problem. Shareholder activism reigns in calculus managerial behaviors.. A substantial majority of the managers held shareholder activism as a measure for improving corporate governance. The remainder of the banks viewed shareholder activism as a requirement by law especially through the traditional medium of AGMs. Some banks in Zimbabwe still view shareholder activism as a requirement by law and not as a measure to improve corporate governance.

\subsection{Data presentation from the interview}

Interviews were conducted with a major institutional shareholder (the interviewee). The questions were open ended in nature so as to elicit deeper responses. Shareholder activism is an important principle of corporate governance in the banking sector. It enhances the level of corporate governance by reducing the agency problem that exists between shareholders and managers.

\subsubsection{Analysis}

The interviewer noted that shareholder activism is an important principle of corporate governance. It promotes good corporate governance practices by reducing the agency problem. There is little shareholder activism in Zimbabwe. Shareholder activism is mainly realised through Annual General Meetings. AGMs exist as required by company law. Directors and managers at times do not involve shareholders in the decision making processes. Shareholder activism needs to be taken seriously if the banking sector is to reduce the risk of corporate failure.

The interviewee highlighted the following ways in which shareholder activism contribute to good governance.

- safeguarding financial resources against loss due to waste, abuse, mismanagement, errors, fraud and other irregularities

- Ensuring that the board is independent.

- having accurate records of transactions producing relevant and reliable financial reports in a timely fashion, including general purpose audited financial statements being fairly presented

In Zimbabwe shareholder activism exists mainly in the form of participation at the Annual General Meeting. The interviewee noted that AGMs are the platforms to monitor and evaluate a corporate entity's performance. In AGMs shareholders can vote for or against resolutions. AGMs can stimulate innovative ideas for the corporate entity. Shareholders are able to safeguard their investments through proposing fair remuneration for directors. They also ensure 
that there is adequate independence within the company board rooms. The interviewee posited that shareholder activism can act as a tool in curbing corporate governance scandals in the banking sector.

\subsection{Data presentation from the Focus Group Discussions (FGDs)}

The Focus Group Discussions (FDGs) sought to unearth the reasons/motives behind shareholder activism. The FDGs also sought to identify the intended targets of shareholder activism. A total of thirty six participants were involved. They were grouped into four groups. This was necessitated largely due to the fact that that it was virtually impossible to conduct an FGD with thirty six participants. The four groups were mixed in nature. Twenty four percent of the participants were shareholders, $29 \%$ were employees of the banks, and the rest was the general public.

\subsubsection{The analysis}

Sixty percent of the respondents argued that targets of shareholder activism are the poorly performing corporate entities. Forty percent noted that shareholder activists tend to have a high portion in the targeted corporate entities. These activists tended to be institutional investors. Shareholder activism is executed mainly to increase shareholder wealth and to reduce the agency problem. Eighty percent of the shareholders argued that shareholder activism improves performance by monitoring and evaluating the corporate entity's activities. A substantial aggregate majority of employees argued that there is no evidence of increased performance as a result of shareholder activism.

\section{Concluding Remarks}

Shareholder activism seeks to improve the level of corporate governance in the banking sector mainly through reducing the agency problem. Corporate governance entails measures that are meant to enhance shareholder value and protecting the funds of depositors while adhering to transparency and accountability. Good corporate governance practices can curb agency costs. Shareholder activism serves an economic watchdog for the investors. Banks should embrace shareholder activism. Shareholder activism should not be viewed as a hindrance but as an active participatory monitoring and evaluation. Investors take risks by investing and rewards for those risks are the return. Investors should have a say, it is after all their funds.

\section{References}

Adegbite, E. (2009). The determinants of good corporate governance: A case of Nigeria. Doctoral Thesis, Cass Business School: City University.

Aguilera, R..V. (2005).Corporate governance and director accountability: An institutional comparative perspective. British Journal of Management, 16, S39-S53.

Aguilera, R.V., \& Jackson, G. (2003).The cross-national diversity of corporate governance: Dimensions and determinants. Academy of Management Review, 28 (3), 447-465.

Anderson, K., Ramsay, I., Marshall., S. \& Mitchell, R. (2007). Union shareholder activism in the context of declining labour law protection: Four Australian case studies. Corporate Governance: An International Review, 15 (1), $45-56$.

Becht, M., Franks, J., Mayer., C. \& Rossi, S. (2006). Returns to shareholder activism: Evidence from a clinical study of the Hermes U.K. Focus Fund. Finance Working Paper 462: London Business School

Black, B. S. (1992). Shareholder Activism and Corporate Governance in the United States. The New Palgrave Dictionary of Economics and the Law, 3, 459-46

Brickley, J.A., Lease, R.C., \& Smith Jr, C.W. (1988). Ownership structure and voting on antitakeover amendments. Journal of Financial Economics 20, 267-291

Chikura, J. (2004). Tackling Key Corporate Governance Issues, The Zimbabwe Independent, 27 August, 2004

Dyck, A., (2001). Privatization and Corporate Governance: Principles, Evidence and Future Challenges. The World Bank Research Observer, 16, 59-84.

Fama, E.F., \& Jensen, M. C. (1983).Separation of ownership and control. Journal of Law and Economics, 26: 301-325.

Gillan, S. L., \& Starks, L. (2007). The evolution of shareholder activism in the United States. Journal of Applied Corporate Finance, 19, $55-73$.

Gillan, S. L., \& Starks, L. T. (2003). Corporate governance, corporate ownership, and the role of institutional investors: A global perspective. Journal of Applied Science, 13(2), 4-22.

Gillan, S.L., \& Starks, L.T. (2000).Corporate governance proposals and shareholder activism: The role of institutional investors. Journal of Financial Economics,57, 275-305. 
Gono, G. (2003). Monetary Policy. Governance: An International Review, 15(2), 173-193.

Jensen, M.C., \& Meckling., W. H. (1976). Theory of the Firm: Managerial Behavior, Agency Costs and Ownership Structure. Journal of Financial economics, 3, 97-118

Mutambanadzo, T., Bhiri, T., \& Makunike, S. (2013).An Analysis Challenges Faced by Zimbabwean Micro Finance Institutions in Providing Financial Services to the Poor and Informal Sector in the Dollarised Regime. Global Journal of Commerce and Management Perspectives, 2(3), 154-159.

Sarkar, J., \& Sarkar, S. (2000). Large shareholder activism in corporate governance in developing countries: Evidence from India. International Review of Finance, 1 (3): 161.

Takawira, G.(2011). Shareholder activism a necessary bitter pill. The Herald, 24 October.

Thompson, T.A.,\& Davis, G.F. (1997).The politics of corporate control and the future of shareholder activism in the United States. Corporate Governance, 5, 1152-1159.

Tsumba, L.L., (2001).Corporate Governance Country Case Experience -Perspectives and Practices: Zimbabwe, Paper presented to the World Bank by the Governor of the Reserve Bank of Zimbabwe. Working Papers Yale School of Management's Legal Scholarship Network 